\title{
Unraveling the structural characteristics of lignin in hydrothermal pretreated fibers and manufactured binderless boards from Eucalyptus grandis
}

Ling-Ping Xiao ${ }^{1 \dagger}$, Zhi Lin ${ }^{2 \dagger}$, Wan-Xi Peng ${ }^{2 *}$, Tong-Qi Yuan ${ }^{1}$, Feng Xu' ${ }^{1}$, Nian-Chun Li², Qing-Song Tao ${ }^{3}$, Hang Xiang ${ }^{4}$ and Run-Cang Sun ${ }^{1,5^{*}}$

\begin{abstract}
Background: Eucalyptus grandis is one of the most abundant biomass from plantation in many parts of the world. The binderless board were manufactured from hydrothermal pretreated fibers of Eucalyptus wood and characterized for the chemical analyses and mechanical strengths in order to assess the mechanism of self-bonding. To make clear the self-bonding mechanism of these binderless boards, the structural characteristics of cellulolytic enzyme lignin (CEL) isolated from Eucalyptus wood, its hydrothermal pretreated fibers, and binderless boards were thoroughly investigated by chemical and spectroscopic methods.
\end{abstract}

Results: The result revealed that hydrothermal pretreatment and hot pressing process could change cellulose crystalline structures by disrupting inter/intra hydrogen bonding of cellulose chains. During the hydrothermal pretreatment of Eucalyptus wood, acid-catalyzed cleavage of $\beta-O-4^{\prime}$ linkages and ester bonds were the major mechanisms of lignin cleavage. This degradation pathway led to a more condensed lignin which has a high average molecular weight and more phenolic hydroxyl groups than the control. The hot pressing process resulted in the binderless boards with reduced lignin contents and decreased the glass transition temperature, thus making the lignin more accessible to the fiber surface. CEL isolated from the binderless boards showed an increased syringyl to guaiacyl propane $(\mathrm{S} / \mathrm{G})$ ratio but a lower molecular weight than those of the untreated Eucalyptus wood and the hydrothermal pretreated fibers.

Conclusions: Based on the finding of this study, it is suggested that the combination of hydrothermal pretreatment and hot pressing process is a good way for conditioning hardwood sawdust for the production of binderless boards. The thermal softening of lignin, rich in phenolic hydroxyl groups, and increased condensed lignin structure contributed to the self-bonding formation of lignocellulosic materials.

Keywords: Hydrothermal pretreatment, Hot pressing, Cellulolytic enzyme lignin, Binderless board, Self-bonding

\section{Background}

The stringent environmental and human health safety regulations and mounting raw material costs have prompted research into reducing the amount of harmful and/or expensive adhesive components and replacing synthetic adhesives with more environmentally-friendly and safer

\footnotetext{
* Correspondence: pengwanxi@163.com; rcsun3@bjfu.edu.cn

${ }^{\dagger}$ Equal contributors

${ }^{2}$ School of Materials and Engineering, Central South University of Forestry and Technology, Changsha 410004, China

'Beijng Key Laboratory of Lignocellulosic Chemistry, Beijing Forestry University, Beijing 100083, China

Full list of author information is available at the end of the article
}

alternatives [1]. Recently, the authors introduced fully green nanotechnology as a gateway to beneficiation of natural cellulose fibers [2-5]. Thermal pretreatment has been conducted in moist environments using hot water or steam at temperatures up to 160 and $240^{\circ} \mathrm{C}$, respectively, or in dry environments using inert gases at temperatures up to $240^{\circ} \mathrm{C}[6,7]$. Under these conditions, hemicelluloses are removed, crystallinity index of cellulose is increased, and cellulose degree of polymerization is reduced, while lignin is not considerably affected $[7,8]$. It seems clear that a thermochemical pretreatment conducted above lignin melting temperature can cause lignin to coalescence, migrate,
(D) Chemistry Central 
and redeposit on biomass cell walls matrix [9]. The softening point of lignin (spherical droplets) after streaming treatment is believed to be lower than that of the original material and this makes it possible for a plastic flow to occur in situ [10]. These lignin droplets were found by hotwater extraction or dilute acid pretreatment of lignocellulosic biomass $[9,11,12]$. Steam pretreatment can cause partial hydrolysis of hemicellulose for both hardwoods and softwoods which markedly increases the compressibility of wood and in turn significantly reduces the build-up of internal stresses in composites during hot pressing $[13,14]$. This steam pretreatment process is a very effective method for producing dimensionally stable wood-based composites [13].

It has been proposed that the pressing temperature is one of the most important manufacturing parameters influencing the binderless boards' properties [15-18]. Okuda et al. $[15,18]$ proposed that parts of lignin and hemicelluloses were decomposed during hot pressing process. Recently, the mechanism of self-bonding was summarized by Fahmy and Mobarak [2], who demonstrated that the chemical changes take place in two stages during hot pressing. The first stage is a hydrolysis stage, whereby acetic and formic acids and some sugars are liberated through the moisture found in the wood particles and then these acids hydrolyze the hemicelluloses in the lignocellulosic material. Some of the pentoses and hexoses produced during hydrolysis are further dehydrated to furfural and hydroxymethyl furfural, respectively. Simultaneously, the lignin becomes activated, i.e., a part of the lignin-carbohydrate bond becomes cleaved (cracked by the formed acids) resulting in the exposition of new functional groups or sites. The second stage is the recondensation reaction of the activated lignin molecules as well as lignin degradation products (such as phenol, which might be formed at high temperature above $155^{\circ} \mathrm{C}$ ) with furfural. However, the self-bonding mechanism during hydrothermal treatment and hot pressing has not been completely elucidated so far.

Traditionally, milled wood lignin (MWL) is considered to be a representative source of native lignin and has been extensively used for the elucidation of native lignin structure. This is currently the most common procedure for the isolation of lignin from wood. However, the yield of MWL is relatively low as revealed by Björkman [19]. Furthermore, lignin yield is dependent on milling time. Nevertheless, longer milling time leads to chemical modification of the lignin, such as increase in carbonyl content and phenolic hydroxyl content as well as decrease in molecular weight and cleavage of aryl ether linkages [20]. Whiting and Goring concluded that MWL is not representative of the whole lignin in wood but primarily originates in the secondary wall of the cell according to the structural studies of dioxane-extracted lignin from compound middle lamella and secondary wall of spruce $[21,22]$. To overcome these limitations, a preparative method combining physical and chemical treatments for lignin isolation and purification, such as milling and enzymatic attack, was recently introduced. Chang et al. [23] isolated lignin by extracting MWL first, and subsequently the residue was treated with cellulolytic enzymes followed by $96 \%$ aqueous dioxane extraction to isolate cellulolytic enzyme lignin (CEL). CEL has higher molecular weights and $\beta-O-4^{\prime}$ inter-linkages, but a lower lignin condensation compared to MWL. The higher yield of CEL extracted from wood helps us understand the lignin structure as a whole. CEL is preferred over MWL for studies of lignin structure as it can be isolated in higher yield with less degradation due to ball milling [23,24].

The objective of this study was to unravel the structural characteristics of lignins of Eucalyptus wood and their behaviors during hydrothermal pretreatment and hot pressing in the production of self-bonding binderless. Because polysaccharides and lignin strongly contribute to self-bonding. This would be also important to understand the differences in mechanical properties of boards from hydrothermal pretreated fibers prepared under various conditions. Moreover, an exhaustive chromatographic and spectroscopic characterization of the isolated CELs was provided as a preliminary investigation.

\section{Results}

\section{Chemical composition}

The chemical compositions of the untreated and pretreated E. grandis as well as the corresponding binderless boards are presented in Table 1. The untreated Eucalyptus feedstock had a typical composition of hardwood with $43.4 \%$ cellulose (determined as glucan), 22.3\% hemicelluloses (determined as galactan, arabian, rhamnan, and glucuronic acid), and $31.7 \%$ lignin (determined as Klason lignin and acid-soluble lignin). These results were comparable with those found in woods from different eucalypt species [25]. The solid yield was slightly affected by the treatment severity and varied from $86.9 \%$ to $96.6 \%$. This was due to the solubilization of amorphous cellulose and the degradation of hemicelluloses or fragile pentoses and hexoses during hydrothermal pretreatment. On average, the Klason lignin contents in the spent solids varied in the range 29.3 $33.2 \%$, and increased up to $16 \%$ of the Klason lignin of the control under harsh conditions. It is worth noting that the Klason lignin content in the binderless boards showed a significant decrease from $33.2 \%$ to $28.0 \%$ as depicted in Table 1. The reduction of lignin content of the Eucalyptus wood after hot pressing resulted in a decrease in the glass transition temperature. It is believed that the softening point of lignin after hydrothermal pretreatment decreased and a possible plastic flow in situ may occur, making the lignin more accessible to the fiber surface $[10,13]$. Thus the 
Table 1 Solid yield and chemical composition of untreated Eucalyptus globule, hydrothermal pretreated fibers, and manufactured binderless boards from Eucalyptus grandis

\begin{tabular}{|c|c|c|c|c|c|c|c|c|c|c|c|c|}
\hline \multirow[t]{2}{*}{ Entry } & \multirow[t]{2}{*}{ Label } & \multirow[t]{2}{*}{ Temperature $\left({ }^{\circ} \mathrm{C}\right)$} & \multirow[t]{2}{*}{ Residence time (h) } & \multirow[t]{2}{*}{ Solid yield } & \multicolumn{8}{|c|}{ Chemical composition ${ }^{\mathrm{a}}(\%)$} \\
\hline & & & & & $\overline{\text { Glu }}$ & Xyl & Gal & Ara & Rha & GIcA & $\mathrm{KL}$ & $\overline{\text { ASL }}$ \\
\hline Control & Raw & - & - & 100 & 43.4 & 18.8 & 1.2 & 0.3 & 0.6 & 1.4 & 28.5 & 3.2 \\
\hline 1 & $\mathrm{~F} 1-\mathrm{a}$ & 150 & 1 & 91.8 & 38.2 & 18.6 & 1.3 & 0.4 & 0.7 & 1.2 & 30.8 & 3.6 \\
\hline 2 & $F 1-b$ & 150 & 1 & - & 42.1 & 17.9 & 1.2 & 0.2 & 1.2 & 1.3 & 27.2 & 3.4 \\
\hline 3 & $\mathrm{~F} 4-\mathrm{a}$ & 150 & 4 & 95.4 & 38.0 & 18.9 & 1.2 & 0.4 & 0.7 & 1.3 & 29.3 & 3.7 \\
\hline 4 & $F 4-b$ & 150 & 4 & - & 42.2 & 18.0 & 1.2 & 0.2 & 0.5 & 1.4 & 26.4 & 3.5 \\
\hline 5 & F8-a & 150 & 8 & 86.9 & 36.7 & 17.9 & 1.1 & 0.4 & 0.6 & 1.1 & 31.0 & 3.5 \\
\hline 6 & F8-b & 150 & 8 & - & 43.3 & 18.3 & 1.1 & 0.2 & 0.5 & 1.3 & 27.4 & 3.2 \\
\hline 7 & Q1-a & 160 & 1.5 & 96.6 & 35.9 & 17.2 & 1.2 & 0.5 & 0.7 & 1.1 & 33.0 & 3.2 \\
\hline 8 & Q1-b & 160 & 1.5 & - & 42.5 & 18.0 & 1.1 & 0.3 & 0.6 & 1.2 & 27.5 & 3.1 \\
\hline 9 & Q2-a & 160 & 3 & 95.8 & 34.8 & 16.7 & 1.3 & 0.6 & 0.7 & 1.0 & 33.2 & 3.1 \\
\hline 10 & Q2-b & 160 & 3 & - & 41.1 & 17.2 & 1.1 & 0.3 & 0.5 & 1.2 & 28.0 & 3.0 \\
\hline 11 & Q3-a & 160 & 4.5 & 95.6 & 36.8 & 17.2 & 1.2 & 0.5 & 0.6 & 1.1 & 32.5 & 3.4 \\
\hline 12 & Q3-b & 160 & 4.5 & - & 41.2 & 17.3 & 1.1 & 0.2 & 0.5 & 1.1 & 28.7 & 3.0 \\
\hline 13 & Q4-a & 160 & 6 & 97.0 & 34.8 & 16.7 & 1.3 & 0.6 & 0.7 & 1.2 & 33.1 & 3.2 \\
\hline 14 & Q4-b & 160 & 6 & - & 42.3 & 19.1 & 1.2 & 0.2 & 0.6 & 1.3 & 28.2 & 3.1 \\
\hline
\end{tabular}

${ }^{a}$ Calculated on basis of the raw material (w/w\%). All the measurements were obtained in triplicate, and the mean value has been indicated. Glu, Glucan;

Xyl, Xylan; Gal, Galactan; Ara, Arabian; Rha, Rhamnan; GlcA, Glucuronic acid; KL, Klason lignin; ASL, Acid-soluble lignin.

thermal softening of lignin plays an important role in the self-bonding mechanism. Other studies have suggested the possibility of the contribution of the cleavage of intermonomer linkages in lignin, such as $\beta$ aryl ether bonds, thus decreasing its molecular weight during the hot pressing process $[15,18]$. Simultaneously, an increase in glucan content was observed in binderless panels as compared to the pretreated Eucalyptus wood.

\section{Mechanical properties of the binderless boards}

Although the primary effect of the study was not to improve the mechanical properties of binderless boards, the effect of hot pressing on the mechanical properties was also investigated. It should be noted that the control panel had so poor mechanical properties that the internal bond (IB) could not be tested. It can be seen from Figure 1 that most of the samples obtained in the present study meet the minimum of requirements of Japanese Industrial Standard A 5908, Type-8, (0.15 MPa) [26] but still lower than the minimum requirements of Chinese Industrial Standard GB/T 11718-2009, (0.40 $\mathrm{MPa}$ [27]. Table 2 shows a summary of the obtained IB values of binderless boards obtained by hydrothermal pretreatment of different lignocellulosic materials at various process conditions. Compared to the summarized results in the previous data in Table 2, in general, the binderless boards in this work demonstrated a comparative promising result. Future work will be conducted to improve the mechanical properties of binderless boards to higher values and thus provide better insights into the understanding of the mechanism during hot pressing.

Generally, it was found that the higher IB of binderless board was obtained under harsh pretreatment severities. This high IB value made from the hydrothermal pretreated E. grandis could be explained based on intermolecular hydrogen bonding between the cellulose and lignin molecule [28]. In accordance with this, a board absorption band appearing in the $3312-3344 \mathrm{~cm}^{-1}$ region in the hydrothermal pretreated fibers and binderless panels indicated $\mathrm{OH}$ stretching in the Fourier-

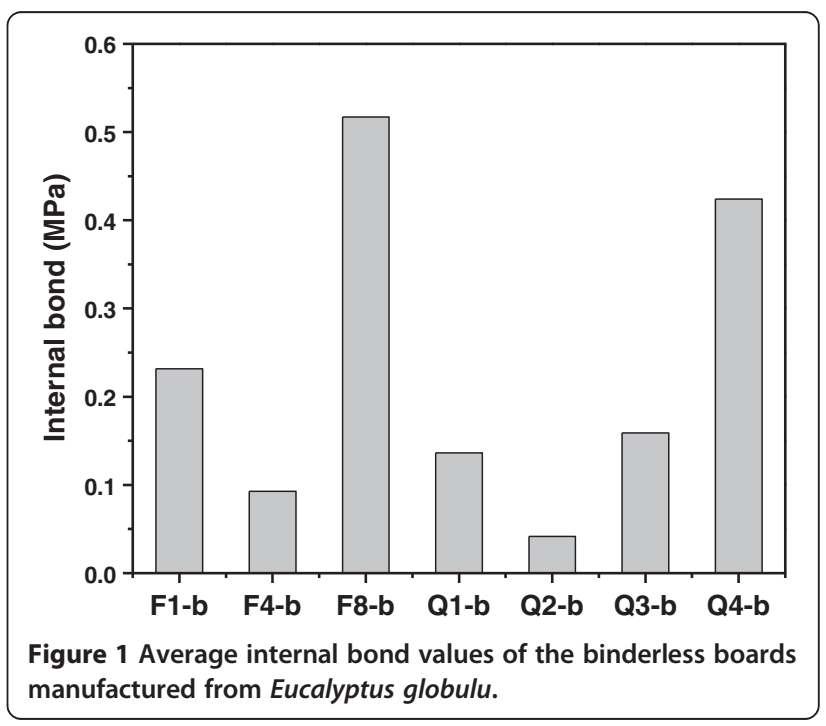


Table 2 Binderless boards prepared from hydrothermal pretreated fibers by various process conditions and the obtained internal bond (IB)

\begin{tabular}{|c|c|c|c|}
\hline Raw material & Process conditions & Internal bond (MPa) & Reference \\
\hline \multirow[t]{2}{*}{ Bamboo (Phyllostachys pubescens) } & Hot water extraction: $60^{\circ} \mathrm{C}, 6 \mathrm{~h}$ & 0.8 & 8 \\
\hline & Hot pressing: $200^{\circ} \mathrm{C}, 10 \mathrm{~min}$ & & \\
\hline \multirow[t]{2}{*}{ Aspen (Populus tremuloides Michx.) and pine (Pinus contorta Dougl.) } & Streaming: $1.55 \mathrm{MPa}, 3 \mathrm{~min}$ & 0.5 & 13 \\
\hline & Hot pressing: $205^{\circ} \mathrm{C}, 4 \mathrm{~min}$ & & \\
\hline \multirow[t]{2}{*}{ Norway spruce (Picea abies Karst) and Scots pine (Pinus sylvestris L.) } & Hydro-thermolysis: $180^{\circ} \mathrm{C}, 30 \mathrm{~min}$ & 0.8 & 14 \\
\hline & Hot pressing: $180^{\circ} \mathrm{C}, 12 \mathrm{~s}$ & & \\
\hline \multirow[t]{2}{*}{ Cynara cardunculus } & Stream explosion: $200^{\circ} \mathrm{C}, 7.5 \mathrm{~min}$ & 0.8 & 17 \\
\hline & Hot pressing: $210^{\circ} \mathrm{C}, 5 \mathrm{~min}$ & & \\
\hline \multirow[t]{2}{*}{ Oil palm trunk waste } & Streaming: $120^{\circ} \mathrm{C}, 46 \mathrm{~min}$ & 0.5 & 28 \\
\hline & Hot pressing: $215^{\circ} \mathrm{C}, 29 \mathrm{~min}$ & & \\
\hline \multirow[t]{2}{*}{ Eucalyptus grandis } & Hot compressed water: $150^{\circ} \mathrm{C}, 8 \mathrm{~h}$ & 0.5 & This work \\
\hline & Hot pressing: $160^{\circ} \mathrm{C}, 20 \mathrm{~min}$ & & \\
\hline
\end{tabular}

transform infrared (FT-IR) spectra in the Supporting information of Additional file 1: Figure S1 and the data shown in Table 3.

\section{Structural changes during hydrothermal pretreatment and hot pressing}

The hydrogen bond intensity (HBI) of cellulose is closely related to the crystal system and the degree of intermolecular regularity, that is, crystallinity, as well as the amount of bound water [29]. The ratio of the absorbance bands at 3400 and $1323 \mathrm{~cm}^{-1}$ was used to study the cellulose samples HBI [29,30]. As quantitative indices for evaluation of the overall crystallinity of cellulose, the lateral order index (LOI) and total crystallinity index (TCI) were determined based on FT-IR spectra. Higher values of TCI and LOI indicate that the materials have a higher crystallinity and more ordered structure of cellulose [31,32]. Low LOI values are indicative of less cellulose type I present [32]. The results obtained are shown in Table 3.

It can be seen from Table 3 that the hydrothermal pretreated fibers and manufactured binderless boards from E. grandis showed higher numbers of HBI, TCI, and LOI than those of the control. This reveals that the cellulose of Eucalyptus wood has a highly ordered crystalline structure and the crystallinity of cellulose increases due to degradation of the amorphous cellulose, which provides a great stability to the cellulose chains and protects them against acid attack during hydrolysis. This finding was in consistent with the results reported in the literature [33]. However, this pretreatment process was unable to completely break apart the inter- and intra- chain hydrogen bondings [34]. The cellulose crystallinity index $(\mathrm{CrI})$ values were also calculated from the corresponding

Table 3 Hydrogen bond intensity and cellulose crystallinity ratios

\begin{tabular}{|c|c|c|c|c|c|}
\hline & \multirow{2}{*}{$\begin{array}{c}\mathrm{HBI}^{\mathrm{a}} \\
\mathrm{A}_{3400} / \mathrm{A}_{1323}\end{array}$} & \multicolumn{2}{|c|}{ FT-IR } & \multirow[t]{2}{*}{$X^{\prime} D^{d}$} & \multirow[t]{2}{*}{$\mathrm{NMR}^{\mathrm{e}}$} \\
\hline & & $\mathrm{TCl}\left(A_{1369} / A_{2900}\right)^{b}$ & LOI $\left(A_{1423} / A_{899}\right)^{c}$ & & \\
\hline Control & 3.46 & 0.48 & 0.99 & 40.53 & 34.83 \\
\hline $\mathrm{F} 1-\mathrm{a}$ & 3.79 & 0.54 & 2.01 & 42.62 & 37.90 \\
\hline F1-b & 4.78 & 0.59 & 1.05 & 46.42 & 40.81 \\
\hline F8-a & 3.84 & 0.55 & 1.83 & 44.82 & 39.41 \\
\hline F8-b & 4.84 & 0.60 & 1.54 & 46.47 & 41.26 \\
\hline Q1-a & 4.06 & 0.50 & 1.86 & 42.68 & 34.83 \\
\hline Q1-b & 4.65 & 0.61 & 1.82 & 45.56 & 37.90 \\
\hline Q4-a & 3.59 & 0.56 & 1.70 & 41.73 & 36.90 \\
\hline Q4-b & 4.10 & 0.60 & 1.67 & 48.64 & 38.99 \\
\hline
\end{tabular}

${ }^{\mathrm{a}} \mathrm{HBI}$ - hydrogen bond intensity which is the ratio of $A_{3400} \mathrm{~cm}^{-1}$ and $A_{1323} \mathrm{~cm}^{-1}$ from FT-IR spectra.

${ }^{\mathrm{b}} \mathrm{TCl}$ - total crystallinity index which is the ratio of $\mathrm{A}_{1369} \mathrm{~cm}^{-1}$ and $\mathrm{A}_{2900} \mathrm{~cm}^{-1}$ from FT-IR spectra.

${ }^{\mathrm{C}} \mathrm{LOI}$ - lateral order index was determined as the ratio of two absorption bands of $A_{1423} \mathrm{~cm}^{-1}$ and $A_{899} \mathrm{~cm}^{-1}$ from FT-IR spectra.

${ }^{\mathrm{d}} \mathrm{Crl}$ was calculated based on the height of the peak corresponding to $(002)$ lattice plane $\left(I_{002}\right)$ and the minimum between 110 and 002 lattice planes $\left(I_{\text {am }}\right)$ as below: $\mathrm{Crl}(\%)=\left(I_{002}-I_{\mathrm{am}}\right) / I_{002}$.

${ }^{\text {e }} \mathrm{Crl}$ was calculated from the ratio of the crystalline area over the total area, where separation of crystalline (86 - $\left.92 \mathrm{ppm}\right)$ and amorphous ( 80 - 86 ppm). 
X-ray diffraction (XRD) patterns (Additional file 1: Figure S2) and solid-state cross polarization/magic angle spinning nuclear magnetic resonance (CP/MAS NMR) patterns (Additional file 1: Figure S3), and the data are listed in Table 3. As the data shown, they were consistent with the conclusion from the FT-IR analysis, and further confirmed that hydrothermal pretreatment and hot pressing can change cellulose crystalline structures by disrupting inter/intra hydrogen bonding of cellulose chains.

\section{FT-IR spectra analysis of the isolated lignins}

The FT-IR spectra of the three CELs are presented in Figure 2, and the IR absorption assignments are based on the literature values [35-38]. It can be seen that the characteristic bands of lignin skeleton and functions of these lignins are very similar. All spectra present typical lignin patterns, including bands of aromatic ring vibrations at $1593 \mathrm{~cm}^{-1}, 1504 \mathrm{~cm}^{-1}$, and $1423 \mathrm{~cm}^{-1}$. Other bands are assigned to ring breathing of syringyl (S) $\left(1326 \mathrm{~cm}^{-1}\right)$ and guaiacyl $(\mathrm{G})$ units $\left(1265 \mathrm{~cm}^{-1}\right.$ shoulder), aromatic in-plane and bending in $\mathrm{S}\left(1122 \mathrm{~cm}^{-1}\right)$ and $\mathrm{G}$ units $\left(1029 \mathrm{~cm}^{-1}\right)$, and out-of-plane $\mathrm{C}-\mathrm{H}$ bending of $\mathrm{G}\left(918 \mathrm{~cm}^{-1}\right)$ and $S$ units $\left(829 \mathrm{~cm}^{-1}\right)$. Moreover, the bands at $1721 \mathrm{~cm}^{-1}$ and $1655 \mathrm{~cm}^{-1}$ correspond to the stretching of non-conjugated and conjugated carbonyls, respectively. No significant difference was detected between the lignin fractions, suggesting little effect of the hydrothermal treatment and hot pressing on the distribution of functional groups in the lignins.

\section{D HSQC NMR of the isolated lignins}

The two-dimensional heteronuclear single quantum coherence (2D HSQC) NMR spectra of the isolated CELs were well resolved as shown in Figure 3. The signals assignments are based on the literature and summarized in Table 4 [39-41], and the main lignin structures identified are shown in Figure 4. The spectra showed mainly lignin moieties, whereas minor polysaccharides, such as hemicelluloses, were present. This is anticipated as most of these carbohydrates were digested due to the enzymatic hydrolysis. In the side region of the HSQC NMR spectra, the cross-signals of methoxyl groups and sidechains in $\beta-O-4$ ' substructures in lignin were the most prominent ones. The $\mathrm{C}-\mathrm{H}$ correlations in substructures (A) were well resolved for $\mathrm{C}_{\gamma}-\mathrm{H}_{\gamma}, \mathrm{C}_{\alpha}-\mathrm{H}_{\alpha}$, and $\mathrm{C}_{\beta}-\mathrm{H}_{\beta}\left(\mathbf{A}_{\gamma}\right.$, $\mathbf{A}_{\boldsymbol{\alpha}}$, and $\mathbf{A}_{\boldsymbol{\beta}}$, respectively). The $\mathrm{C}_{\beta}-\mathrm{H}_{\beta}$ correlations gave two different signals corresponding to $\beta-O-4$ ' subunit which linked to $G$ and $S$ units $\left(\mathbf{A}_{\boldsymbol{\beta}(\mathbf{G})}\right.$ and $\mathbf{A}_{\boldsymbol{\beta}(\mathbf{S})}$, respectively). The presence of resinol $\left(\beta-\beta^{\prime}\right)$ substructures (B) was evidenced by $\mathrm{C} / \mathrm{H}$ correlations for $\alpha-, \beta-$, and $\gamma-\mathrm{C}$ positions centered at $\delta_{\mathrm{C}} / \delta_{\mathrm{H}} 85.1 / 4.66,53.4 / 3.06$, and $71.7 / 3.81$ and $4.18 \mathrm{ppm}$, respectively. Lignin phenylcoumaran $\left(\beta-5^{\prime}\right)$ substructure $(\mathbf{C})$ was also confirmed by its $\mathrm{C}-\mathrm{H}$ correlations at around 86.8/5.45 $\left(\mathrm{C}_{\alpha}-\mathrm{H}_{\alpha}\right), 53.1 / 3.47$ $\left(\mathrm{C}_{\beta}-\mathrm{H}_{\beta}\right)$, and 63.2/3.70 $\left(\mathrm{C}_{\gamma}-\mathrm{H}_{\gamma}\right)$ ppm. Finally, small signals corresponding to spirodienone $\mathrm{C}_{\gamma}-\mathrm{H}_{\gamma}$ in $p$-hydroxycinnamyl alcohol end groups (F) could be also found in the spectra, its $\mathrm{C}_{\beta}-\mathrm{H}_{\beta}$ correlations being at 61.3/4.09 ppm.

The main cross-signals observed in the aromatic region of the HSQC NMR spectra belong to the aromatic rings of lignin monomers. Correlations from $\mathrm{S}$ and $\mathrm{G}$

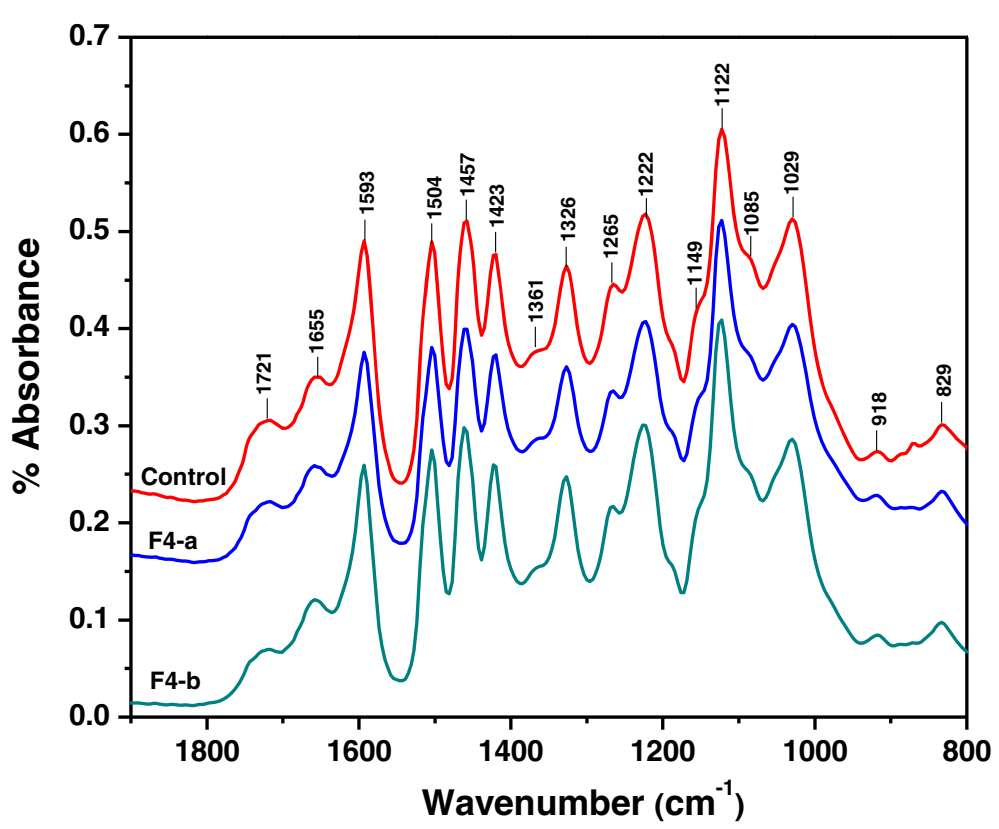

Figure 2 FT-IR spectra of the CEL samples. 


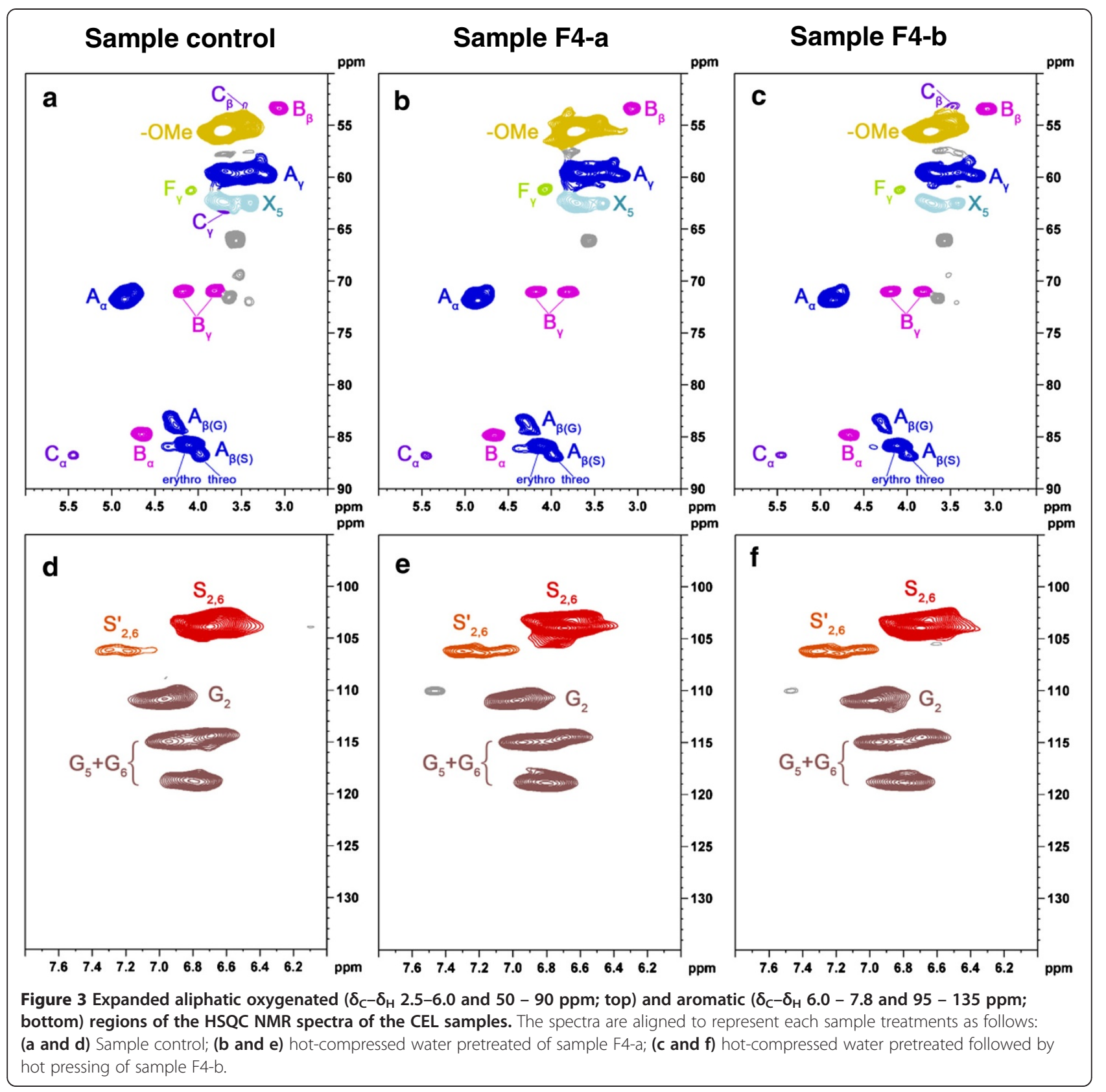

lignin units could be observed in the spectra of the CELs. Strong $\mathrm{C}_{2,6}-\mathrm{H}_{2,6}$ correlations for syringyl $\left(\mathbf{S}_{\mathbf{2 , 6}}\right)$ and $\mathrm{C}_{\alpha}$-oxidized $\mathrm{S}$-lignin units $\left(\mathbf{S}^{\prime}\right)$ were observed at 103.9/6.69 ppm and 106.2/7.19 ppm, respectively. For guaiacyl $(\mathbf{G})$ units, $\mathbf{G}_{\mathbf{2}}$ correlation was observed at 111.1/ $6.96 \mathrm{ppm}$ and correlations for $\mathbf{G}_{\mathbf{5}} / \mathbf{G}_{\mathbf{6}}$ were observed at $115.0 / 6.64$ and $6.91 \mathrm{ppm}$, and 119.0/6.82 $\mathrm{ppm}$.

Summary of changes in lignin structure as revealed by 2D HSQC NMR

The relative abundances of the main lignin inter-unit linkages and the S/G ratio, calculated from the HSQC spectra of the CELs, are shown in Table 5. All the lignins showed a predominance of $\beta-O-4$ units (A; $79-81 \%$ of the total side chains) followed by $\beta-\beta$ ' resinol type units $(\mathbf{B} ; 16-$ $17 \%)$. The $\beta-5^{\prime}$ phenylcoumaran type lignin unit $\left(\mathbf{C}_{\boldsymbol{\alpha}}\right)$ ranged from $3.2 \%$ to $3.6 \%$. The slight decrease amount of $\beta-O-4{ }^{\prime}$ was anticipated. Under high temperature and pressure water causes an auto-catalyzed cleavage of glycosidic bond in hemicelluloses and lignin-hemicellulose linkages, thus producing acetic acid from the acetyl groups. Therefore, the acidic environment during hydrothermal processes probably resulted in the partial hydrolysis of ether linkages $[42,43]$. On the other hand, the relative content of C-C 
Table 4 Assignments of main lignin and polysaccharide ${ }^{13} \mathrm{C}-{ }^{1} \mathrm{H}$ correlation signals in the HSQC spectra the lignin fractions

\begin{tabular}{|c|c|c|}
\hline Labels & $\delta_{\mathrm{C}} / \delta_{\mathrm{H}}(\mathrm{ppm})$ & Assignment \\
\hline$\overline{C_{\beta}}$ & $53.1 / 3.47$ & $\begin{array}{l}\mathrm{C}_{\beta}-\mathrm{H}_{\beta} \text { in phenylcoumaran } \\
\text { substructures (C) }\end{array}$ \\
\hline $\mathrm{B}_{\beta}$ & $53.4 / 3.06$ & $\mathrm{C}_{\beta}-\mathrm{H}_{\beta}$ in resinol substructures (B) \\
\hline -OMe & $55.6 / 3.72$ & $\mathrm{C}-\mathrm{H}$ in methoxyls (MeO) \\
\hline$A_{\gamma}$ & $60.0 / 3.40-3.69$ & $C_{\gamma}-H_{\gamma}$ in $\beta-O-4^{\prime}$ substructures (A) \\
\hline $\mathrm{F}_{\mathrm{v}}$ & $61.3 / 4.09$ & $\begin{array}{l}\mathrm{C}_{Y}-\mathrm{H}_{Y} \text { in } p \text {-hydroxycinnamyl } \\
\text { alcohol end groups (F) }\end{array}$ \\
\hline$C_{\gamma}$ & $63.2 / 3.70$ & $\begin{array}{l}\mathrm{C}_{Y}-\mathrm{H}_{Y} \text { in phenylcoumaran } \\
\text { substructures (C) }\end{array}$ \\
\hline $\mathrm{B}_{\gamma}$ & $71.7 / 3.81$ and 4.18 & $\mathrm{C}_{\gamma}-\mathrm{H}_{\gamma}$ in resinol substructures (B) \\
\hline$A_{a}$ & $71.8 / 4.85$ & $\mathrm{C}_{a}-\mathrm{H}_{a}$ in $\beta-O-4^{\prime}$ substructures (A) \\
\hline$A_{\beta(G)}$ & $84.1 / 4.27$ & $\begin{array}{l}\mathrm{C}_{\beta}-\mathrm{H}_{\beta} \text { in } \beta-O-4^{\prime} \text { substructures } \\
\text { linked to a } \mathrm{G} \text { unit (A) }\end{array}$ \\
\hline$B_{a}$ & $85.1 / 4.66$ & $\mathrm{C}_{a}-\mathrm{H}_{a}$ in resinol substructures (B) \\
\hline $\mathrm{C}_{\mathrm{a}}$ & $86.8 / 5.45$ & $\begin{array}{l}\mathrm{C}_{a}-\mathrm{H}_{a} \text { in phenylcoumaran } \\
\text { substructures (C) }\end{array}$ \\
\hline$A_{\beta(S)}$ & $86.1 / 4.11$ & $\begin{array}{l}C_{\beta}-H_{\beta} \text { in } \beta-O-4 \text { ' substructures } \\
\text { linked to a } S \text { unit }(\mathbf{A})\end{array}$ \\
\hline$S_{2,6}$ & 103.9/6.69 & $\begin{array}{l}\mathrm{C}_{2,6}-\mathrm{H}_{2,6} \text { in etherified syringyl } \\
\text { units (S) }\end{array}$ \\
\hline$S_{2,6}^{\prime}$ & 106.2/7.19 & $\begin{array}{l}\mathrm{C}_{2,6}-\mathrm{H}_{2,6} \text { in oxidized }\left(\mathrm{C}_{a}=\mathrm{O}\right) \\
\text { phenolic syringyl units }\left(\mathbf{S}^{\prime}\right)\end{array}$ \\
\hline $\mathrm{G}_{2}$ & $111.1 / 6.96$ & $\mathrm{C}_{2}-\mathrm{H}_{2}$ in guaiacyl units (G) \\
\hline $\mathrm{G}_{5} / \mathrm{G}_{6}$ & $115.0 / 6.64$ and $6.91 ; 119.0 /, 6.82$ & $\begin{array}{l}\mathrm{C}_{5}-\mathrm{H}_{5} \text { and } \mathrm{C}_{6}-\mathrm{H}_{6} \text { in guaiacyl } \\
\text { units (G) }\end{array}$ \\
\hline
\end{tabular}

linkages (such as $\beta-\beta$ ' linkages) increased, demonstrating that the lignin became more condensed.

It was found that the $S / G$ ratio and the signal of $\mathrm{C}_{\alpha^{-}}$ oxidized S-lignin units $\left(\mathbf{S}^{\prime}\right)$ increased. The CEL of the untreated sample $E$. grandis which had a proportion of
S/G ratio at around 1.7 (Table 5), became a S-rich lignin after hydrothermal pretreatment and hot pressing. The result is consistent with our recent work in which we observed that the S/G ratio of shrub wood lignin, analyzed by pyrolysis-gas chromatography/mass spectrometry (Py-GC/MS) and 2D HSQC NMR, increased with the increment of hydrothermal pretreatment severity [44]. Similar results have been reported by Okuda et al. [15] who found that the S/V ratio increased with increasing pressing temperature. This result could have been due to the preferential degradation of low molecular weight of no-condensed G-type lignin during the treatment. Higher thermal stability of the $\beta$-aryl ether linkages of syringyl present as compared to guaiacyltype lignin in hardwood make the later one lost during hydrothermal pretreatment and hot pressing [1]. Thus a more pronounced decrease in $\mathrm{G}$ units compared to $\mathrm{S}$ units likely accounted for the increased S/G ratio of lignin from 1.7 (Control) to 2.4 (F4-b). Moreover, a recent work has demonstrated that the presence of these oxidized S' units in eucalypt wood might be an artifact of the milling process $[45,46]$. However, all the samples in the present study were planetary ball milled under the same conditions, demonstrating that the variation was due to the differences in the composition of the biomass. After electron transfer and aryl cation radical formation, aromatic ring oxidation has been reported in model degradation by laccase-HBT, whereas the $C_{\alpha}$ attack followed by alkyl-aryl ether breakdown predominates, thus resulted in an increase in the amount of $\mathrm{C}_{\alpha}$-oxidized $\mathrm{S}$ lignin $[47,48]$. The proposed mechanism was through the Baeyer-Villiger reaction which may be similar to the mechanism of hot pressing in the present study. Furthermore, this can be rationalized due to the basis that nonphenolic lignin compounds was oxidized and cleaved during hot pressing process and that the action of hot<smiles>CCCCCCCCCCCC</smiles>

A<smiles>CC1CCC(c2ccccc2)CC1C1CCC(c2ccccc2)OC1</smiles>

B

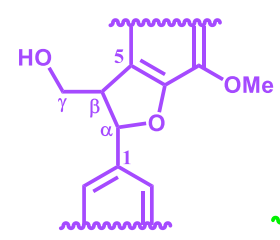

C

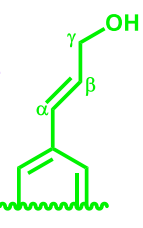

F

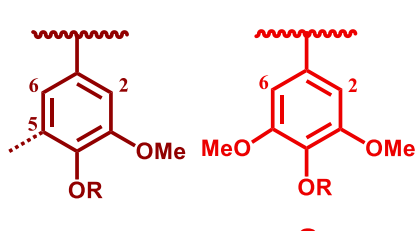<smiles>COc1cc(C(=O)C(C)C)cc(OC)c1O</smiles>

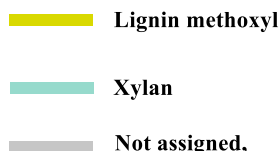

$S^{\prime}$

Not assigned, currently unresolved

Figure 4 Main substructures present. A, $\beta$-aryl ether structure formed by $\beta-O-4^{\prime}$ linkages; B, resinol including $\beta-\beta^{\prime}$ linkages; $C$, phenylcoumaran including $\beta$-5' linkages; $F, p$-hydroxycinnamyl alcohol end groups; $G$, Guaiacyl unit; $S$, Syringyl unit; $S^{\prime}$, Oxidized syringyl units bearing a carboxyl group at $C_{a}$. 
Table 5 Lignin structural characteristics from integration of ${ }^{13} \mathrm{C}-{ }^{1} \mathrm{H}$ correlation signals in the HSQC spectra the lignin fractions

\begin{tabular}{lccc}
\hline & Control & F4-a & F4-b \\
\hline Lignin interunit linkages (\%) & & & \\
$\beta-O-4^{\prime}$ aryl ether (A) & 80.7 & 80.1 & 79.0 \\
Resinol substructures (B) & 16.1 & 17.0 & 17.4 \\
Phenylcoumaran (C) & 3.2 & 2.9 & 3.6 \\
Lignin aromatic units & & & \\
S/G ratio & 1.7 & 2.0 & 2.1 \\
S/S' ratio & 3.8 & 6.9 & 7.0 \\
\hline
\end{tabular}

pressing couple proceeds via $\mathrm{C}_{\alpha}$-hydrogen atom abstraction [49].

\section{${ }^{31} \mathrm{P}$ NMR spectra of the lignin polymers}

To further investigate the structural changes of lignin during hydrothermal pretreatment and hot pressing process, quantitative ${ }^{31} \mathrm{P}$ NMR analysis was performed using 2-chloro-4,4,5,5-tetramethyl-1,3,2-dioxaphos pholane (TMDP) as phosphorylation reagent [50]. Data from the quantitative ${ }^{31} \mathrm{P}$ NMR spectra of the CELs samples are presented in Table 6 and Figure 5. The concentration of each hydroxyl functional (in $\mathrm{mmol} / \mathrm{g}$ ) was calculated on the basis of the hydrolysis content of the internal standard and its integrated peak area.

It can be seen from Table 6, a slight increase in aliphatic $\mathrm{OH}$ concentration was observed after hydrothermal pretreatment. This was because higher pretreatment severity led to greater reductions in $\beta-O-4$ structures, resulting increase in a higher amount of free phenolic groups [51]. Moreover, a post-treatment with hot pressing process was accompanied by a slight decrease in the aliphatic $\mathrm{OH}$ but an increase of $\mathrm{S}-\mathrm{OH}$. This was most likely as a result of acid-catalyzed elimination reactions thus led to a cleavage of $\beta-O-4$ linakges [52]. The fact that the more syringyl units are produced during hydrothermal treatment, such as steam explosion treatment, most likely as a result of scission of $\beta-O-4$ bonds, has already been supported by Granata and Argyropoulos [50]. In addition, loss of carboxylic hydroxyl group can be observed in the resulting CELs obtained from the hydrothermal treatment and hot pressing.

\section{Molecular weight distribution of the isolated lignins}

To investigate the effect of hydrothermal and hot pressing treatment process on the molecular weights of lignin fractions, the gel permeation chromatography (GPC) elution curves of the three CEL samples were recorded as depicted in Figure 6 and the dada are summarized in Table 6. It was observed that CEL-F4-a had a higher $M_{w}$ than that of the control. This observation confirmed that lignin repolymerization occurred during hydrothermal pretreatment, which was due to acid-catalyzed condensation between the aromatic $\mathrm{C} 6$ or $\mathrm{C} 5$ and a carbonium ion at a higher severity $[43,53]$. In this regard, during the hydrothermal pretreatment of Eucalyptus wood, acidcatalyzed cleavage of $\beta-O-4^{\prime}$ linkages and ester bonds were the major mechanisms of lignin cleavage. After hot pressing process, the $M_{w}$ was decreased to $16600 \mathrm{~g} / \mathrm{mol}$, which was slightly lower than that of the control. This suggested that hot pressing process degraded the lignin macromolecular polymer in the hydrothermal pretreated fibers to a noticeable extent, which confirmed the aforementioned reduction contents of $\beta-O-4$ ' linkages as determined by $2 \mathrm{D}$ HSQC and ${ }^{31} \mathrm{P}$ NMR.

\section{Conclusions}

The result showed that during the hydrothermal pretreatment of Eucalyptus wood, acid-catalyzed cleavage of $\beta-O-4{ }^{\prime}$ linkages and ester bonds were the major mechanisms of lignin cleavage. This degradation pathway led to a more condensed lignin that has a high average molecular weight and more phenolic hydroxyl groups than those of the control. The hot pressing process resulted in the binderless boards with reduced lignin contents and decreased the glass transition temperature, thus making the lignin more accessible to the fiber surface. CEL isolated from the binderless boards showed an increased syringyl to guaiacyl propane $(\mathrm{S} / \mathrm{G})$ ratio but a lower molecular weight than that of the untreated Eucalyptus wood and the hydrothermal pretreated fibers. Moreover, Eucalyptus wood has the potential to be used to manufacture binderless boards. Based on the finding of this study, it is suggested that the combination of hydrothermal pretreatment and hot pressing process is a good way for conditioning hardwood sawdust for the production of binderless boards. The thermal softening of lignin,

Table 6 Concentrations of functional groups and molecular weight distributions of the lignin fractions

\begin{tabular}{|c|c|c|c|c|c|c|c|c|c|c|}
\hline \multirow[t]{2}{*}{ Lignin sample } & \multicolumn{7}{|c|}{ Functional groups concentration $(\mathrm{mmol} / \mathrm{g})^{a}$} & \multicolumn{3}{|c|}{ Molecular weight $(\mathrm{g} / \mathrm{mol})^{\mathrm{b}}$} \\
\hline & AlkOH & Cond. PhOH & $\mathrm{S}-\mathrm{OH}$ & $\mathrm{G}-\mathrm{OH}$ & $\mathrm{H}-\mathrm{OH}$ & $\mathrm{COOH}$ & Total OH & $M_{w}$ & $M_{n}$ & $M_{w} / M_{n}$ \\
\hline Control & 4.61 & 0.21 & 0.24 & 0.51 & 0.14 & 0.11 & 5.82 & 16800 & 7460 & 2.25 \\
\hline F4-a & 5.08 & 0.16 & 0.26 & 0.45 & 0.07 & 0.08 & 6.10 & 17500 & 7660 & 2.29 \\
\hline$F 4-b$ & 4.94 & 0.16 & 0.30 & 0.42 & 0.06 & 0.08 & 5.96 & 16600 & 7440 & 2.23 \\
\hline
\end{tabular}

${ }^{\mathrm{a}}$ Quantitative ${ }^{31} \mathrm{P}$ NMR determination of functional groups: AlkOH, aliphatic hydroxyl; cond. PhOH, condensed phenolic hydroxyl; S-OH, syringyl hydroxyl; G-OH, guaiacyl hydroxyl; $\mathrm{H}-\mathrm{OH}$, p-hydroxyphenyl hydroxyl; and $\mathrm{COOH}$, carboxylic groups.

${ }^{\mathrm{b}} \mathrm{M}_{\mathrm{w}}$, weight average molecular weight; $\mathrm{M}_{\mathrm{n}}$, number average molecular weight. 


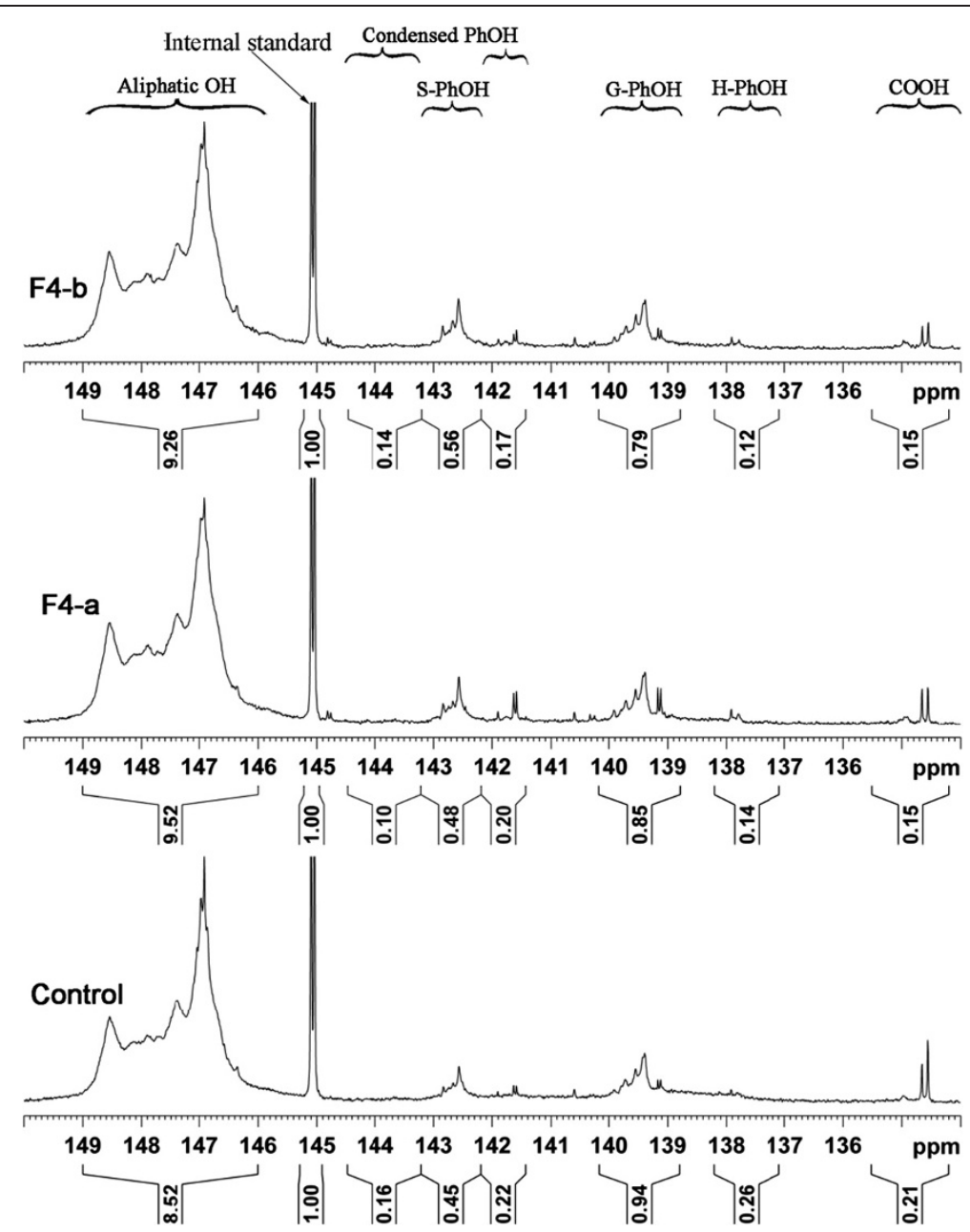

Figure 5 Quantitative ${ }^{31} \mathrm{P}$ NMR of the CEL samples.

rich in phenolic hydroxyl groups, and increased condensed lignin structure contributed to the self-bonding formation of lignocellulosic materials. Future work will be conducted to optimize the pretreatment conditions and improve the performance of binderless board to higher values and commercial uses.

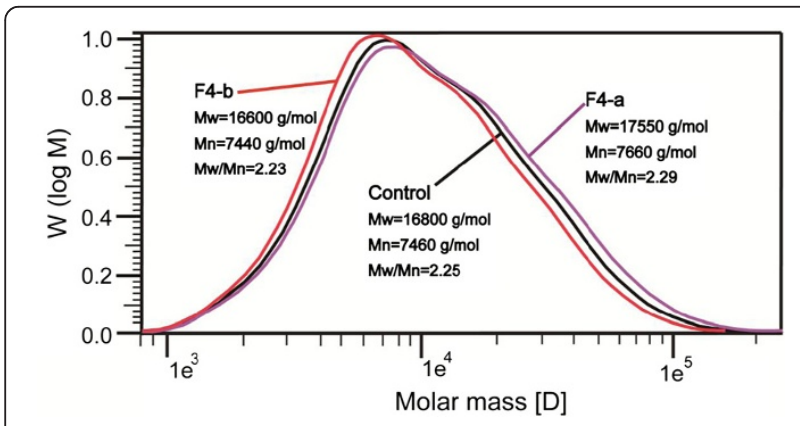

Figure 6 Molecular weight distributions of the CEL samples.

\section{Methods}

Materials

Eucalyptus grandis $x$ E. urophylla, five years old, was manually collected from Hezhou City, Guanxi province, China. The dried Eucalyptus stems were ground to pass a 40-mesh screen. All chemical reagents were analytical grade or best available. The acid xylanase and cellulase with declared activities of 100,000 international units (IU) per gram of protein and 145 filter paper units (FPU)/g were kindly provided by Shanghai Youtell Biochemical Co., Ltd. (Shanghai China).

\section{Hydrothermal pretreatment of Eucalyptus wood}

The wood meals of Eucalyptus (100 g dry basis per batch) were added into a batch reactor (1 litter volume). For hot water extraction, the sample was treated under desired temperature $150^{\circ} \mathrm{C}$ and digestion periods $(1,4$, and $8 \mathrm{~h}$ ). For steam pretreatment, the sample was treated under desired temperature $160^{\circ} \mathrm{C}$ and digestion periods $(1.5,3,4.5$, and $6 \mathrm{~h}$ ). Defibrillated fibers were collected to prepare 
binderless boards and denoted as F1-a, F4-a, F8-a, Q1-a, Q2-a, Q3-a, and Q4-a, respectively.

\section{Binderless board preparation and mechanical characterization of the boards}

Each air-dried sample of powders was hand-formed into homogeneous single-layered mats using a forming box $\left(50 \times 50 \mathrm{~cm}^{2}\right)$ and pressed at a pressure of $15 \mathrm{MPa}$ at $160^{\circ} \mathrm{C}$ for $20 \mathrm{~min}$, by adjusting the target board thickness to $5.0 \mathrm{~mm}$ and the density to $1.0 \mathrm{~g} / \mathrm{cm}^{3}$. Two boards were prepared for each powder. The hydrothermal pretreated Eucalyptus fibers were dried to $10 \%$ moisture content under air-dried condition. The binderless boards were prepared on a laboratory sale by the standard techniques under controlled conditions. The manufactured binderless boards from the defibrillated fibers were denoted as F1-b, F4-b, F8-b, Q1-b, Q2-b, Q3-b, and Q4-b, respectively.

The properties of the binderless boards were evaluated in accordance with China National Standard for fiberboards [27,54]. The five specimens of $25.4 \times 25.4 \times 1.25 \mathrm{~cm}^{3}$ were prepared. The internal bonding strength (IB) test, regarded as the index of self-bonding, was carried out by using a universal testing machine.

\section{Isolation of CEL}

To investigate the original lignin polymers of the untreated and pretreated Eucalyptus wood as well as the binderless board, cellulolytic enzyme lignin (CEL) were isolated according to the procedure developed by Chang et al. [23] and modified by $\mathrm{Hu}$ et al. [24]. Specifically, ball milled wood $(5 \mathrm{~g})$ was suspended in citrate buffer $(250 \mathrm{~mL}, \mathrm{pH} 4.8)$ and incubated for $24 \mathrm{~h}$ at $50^{\circ} \mathrm{C}$. The cellulase and acid xylanase were used at a loading of 50 FPU/g substrate and $200 \mathrm{IU} / \mathrm{g}$ substrate, respectively, to hydrolyze the cellulose and hemicelluloses. The enzyme treatment was repeated twice. The residue was collected by centrifugation, washed with hot distilled water $(200$ $\mathrm{mL})$, centrifuged, and freeze-dried. Then the freeze-dried residue was extracted twice $(2 \times 24 \mathrm{~h})$ with $100 \mathrm{~mL}$ of dioxane/water $(96: 4, \mathrm{v} / \mathrm{v})$ under a nitrogen atmosphere. After each extraction, the supernatant was collected, combined and poured into a $250 \mathrm{~mL}$ volumetric flask. Subsequently, the solution was concentrated, precipitated in water, and freeze-dried to produce the CEL.

\section{Physicochemical characterization of the Eucalyptus wood, hydrothermal pretreated fibers, and binderless boards}

The chemical compositions of the extractive-free Eucalyptus wood, hydrothermal pretreated fibers and binderless boards were determined according to National Renewable Energy Laboratory Analytical Procedures [55]. FT-IR spectra were acquired using a Thermo Scientific Nicolet iN10 FT-IR Microscope as previously described [44]. The crystallinities of the samples were measured using a XRD6000 instrument (Shimadzu, Japan) [11]. CP/MAS ${ }^{13} \mathrm{C}$ NMR spectra of the different samples were obtained using a Bruker AVIII $400 \mathrm{M}$ spectrometer (Germany) [11].

\section{Characterization of the lignin polymers}

FT-IR spectra of the CELs were performed the same as raw material. The weight average molecular weight $\left(\mathrm{M}_{\mathrm{w}}\right)$ and number average molecular weight $\left(M_{n}\right)$ of the CELs were performed with GPC after acetylation according to previous publications [56,57]. Briefly, about $20 \mathrm{mg}$ of dry lignin was dissolved in a 1:1 mixture of acetic anhydride/pyridine (1.00 $\mathrm{mL}$ ) and stirred at room temperature for $24 \mathrm{~h}$. Ethanol $(25.0 \mathrm{~mL})$ was added to the reaction mixture, left for 30 min, and removed with a rotary evaporator. The addition and removal of ethanol was repeated until all traces of acetic acid were removed from the sample. The residue was dissolved in chloroform $(2.0 \mathrm{~mL})$ and drop-wise to diethyl ether $(100.0 \mathrm{~mL})$ followed by centrifugation. The precipitate was washed three times with diethyl ether and dried under vacuum prior to GPC analysis. The acetylated lignin was dissolved in tetrahydrofuran (THF) $(2 \mathrm{mg} / \mathrm{mL})$, and the solution was filtered through a $0.45 \mu \mathrm{m}$ filter. The filtered solution $(20.0 \mu \mathrm{L})$ was injected into the HPLC system and detected using an UV detector set at $240 \mathrm{~nm}$. THF was used as the mobile phase and the flow rate was $0.5 \mathrm{~mL} /$ min. Standard narrow polystyrene samples were used for calibration, as described previously [44].

For 2D HSQC spectra, the Bruker standard pulse program hsqcetgpsi was used for HSQC experiments as previously described [44]. ${ }^{31} \mathrm{P}$ NMR spectra were acquired according to a previous paper with minor modifications [50]. A total of $20 \mathrm{mg}$ lignin was dissolved in $0.5 \mathrm{~mL}$ of anhydrous pyridine and deuterated chloroform $(1.6: 1, \mathrm{v} / \mathrm{v})$ under stirring. This was followed by the addition of $0.1 \mu \mathrm{L}$ of cyclohexanol $(10.85 \mathrm{mg} / \mathrm{mL})$ as an internal standard, and $0.1 \mu \mathrm{L}$ of chromium(III) acetylacetonate solution $(5 \mathrm{mg} / \mathrm{mL}$ in anhydrous pyridine and deuterated chloroform 1.6:1, v/v), as relaxation reagents. Finally, the mixture was reacted with $0.1 \mu \mathrm{L}$ of phosphitylating reagent (2chloro-1,3,2-dioxaphospholane) for $15 \mathrm{~min}$ and then was transferred into a $5 \mathrm{~mm}$ NMR tube for subsequent NMR analysis. Acquisition conditions were as described previously [50]. The content of hydroxyl groups in lignin was obtained by integration of the following spectral regions as described by Cateto et al. [58] and Monteil-Rivera et al. [59] with miner modification: aliphatic hydroxyls (149.0 - $146.0 \mathrm{ppm}$ ), syringyl (S) phenolic hydroxyls $(144.5-143.2 \mathrm{ppm})$, condensed phenolic units (difference between the integrals of the peaks at $143.2-142.2 \mathrm{ppm}$ and those at 142.2 - $141.4 \mathrm{ppm}$, guaiacyl (G) phenolic hydroxyls (140.2 - $138.7 \mathrm{ppm}), p$-hydroxyphenyl $(\mathrm{H})$ phenolic hydroxyls (138.2 - $137.1 \mathrm{ppm})$, and carboxylic acids (135.5 - $134.2 \mathrm{ppm})$. 


\section{Additional file}

Additional file 1: Figure S1. FT-IR spectra of the untreated Eucalyptus grandis, hydrothermal pretreated fibers, and binderless boards. Figure S2. XRD spectra of the untreated Eucalyptus grandis, hydrothermal pretreated fibers, and binderless boards. Peaks around $2 \theta$ of $16^{\circ}$ and $22^{\circ}$ correspond to (101) and (002) lattice diffraction, respectively. Figure S3. CP/MAS ${ }^{13} \mathrm{C}$ NMR spectra of the untreated Eucalyptus grandis, hydrothermal pretreated fibers, and binderless boards.

\section{Abbreviations}

Ara: Arabian; ASL: Acid-soluble lignin; CEL: Cellulolytic enzyme lignin; Crl: Cellulose crystallinity index; CP/MAS NMR: Cross polarization/magic angle spinning nuclear magnetic resonance; FPU: Filter paper unit; FT-IR: Fourier transform infrared spectroscopy; G: Guaiacyl; Gal: Galactan; Glu: Glucan; GPC: Gel permeation chromatography; GlcA: Glucuronic acid; HBI: Hydrogen bond intensity; HSQC: Heteronuclear single quantum coherence; IB: Internal bond; IU: International unit; KL: Klason lignin; LOI: Lateral order index; MWL: Milled wood lignin; $M_{w}$ : Weight average molecular weight; $M_{n}$ : Number average molecular weight; Py-GC/MS: Pyrolysis gas chromatography/mass spectrometry; Rha: Rhamnan; S: Syringyl; TCl: Total crystallinity index; TMDP: 2-chloro-4, 4, 5, 5-tetramethyl-1, 3, 2dioxaphospholane; XRD: X-ray diffraction; Xyl: Xylan.

\section{Competing interests}

The authors declare that they have no competing interests.

\section{Authors' contributions}

LPX carried out the characterization, data analyses, and drafted the manuscript. ZL provided the Eucalyptus grandis wood and performed the biomass pretreatment and the production of binderless board. WXP and RCS supervised the entire study and contributed to experimental design, manuscript planning, and reviewed the manuscript. All authors read and approved the final manuscript.

\section{Acknowledgements}

The authors are grateful for the financial support from the State Forestry Administration (201204803), National 863 Project (863-2012AA023204), Major State Basic Research Projects of China (973-2010CB732204), and the Specific Programs in Graduate Science and Technology Innovation of Beijing Forestry University (BLYJ201314).

\section{Author details}

${ }^{1}$ Beijng Key Laboratory of Lignocellulosic Chemistry, Beijing Forestry University, Beijing 100083, China. ${ }^{2}$ School of Materials and Engineering, Central South University of Forestry and Technology, Changsha 410004, China. ${ }^{3}$ Jiangxi JooMuTang Bamboo Flooring Co., Ltd., Nanchang 330052, China. ${ }^{4}$ Hunan Yuanhang Biotechnology Co., Ltd., Wangcheng 410200, China. ${ }^{5}$ State Key Laboratory of Pulp and Paper Engineering, South China University of Technology, Guangzhou 510640, China.

Received: 17 December 2013 Accepted: 4 April 2014 Published: 11 April 2014

\section{References}

1. Widsten $P$, Kandelbauer A: Adhesion improvement of lignocellulosic products by enzymatic pre-treatment. Biotechnol Adv 2008, 26:379-386.

2. Fahmy TYA, Mobarak F: Advanced binderless board-like green nanocomposites from undebarked cotton stalks and mechanism of self-bonding. Cellulose 2013, 20:1453-1457.

3. Fahmy TYA, Mobarak F, Fahmy Y, Fadl MH, El-Sakhawy M: Nanocomposites from natural cellulose fibers incorporated with sucrose. Wood Sci Technol 2006, 40:77-86.

4. Fahmy TYA, Mobarak F: Nanocomposites from natural cellulose fibers filled with kaolin in presence of sucrose. Carbohydr Polym 2008, 72:751-755.

5. Fahmy TYA, Mobarak F: Vaccination of biological cellulose fibers with glucose: a gateway to novel nanocomposites. Int J Biol Macromol 2008, 42:52-54.
6. Xiao LP, Shi Z, Xu F, Sun RC: Hydrothermal treatment and enzymatic hydrolysis of Tamarix ramosissima: evaluation of the process as a conversion method in a biorefinery concept. Bioresour Technol 2013, 135:73-81.

7. Pelaez-Samaniego MR, Yadama V, Lowell E, Espinoza-Herrera R: A review of wood thermal pretreatments to improve wood composite properties. Wood Sci Technol 2013, 7:1321-1322.

8. Saito Y, Ishii M, Sato M: The suitable harvesting season and the part of moso bamboo (Phyllostachys pubescens) for producing binderless boards. Wood Sci Technol 2013, 47:1071-1081.

9. Donohoe BS, Decker SR, Tucker MP, Himmel ME, Vinzant TB: Visualizing lignin coalescence and migration through maize cell walls following thermochemical pretreatment. Biotechnol Bioeng 2008, 101:913-925.

10. Anglès MN, Ferrando F, Farriol X, Salvadó J: Suitability of steam exploded residual softwood for the production of binderless panels: effect of the pretreatment severity and lignin addition. Biomass Bioenergy 2001, 21:211-224.

11. Xiao LP, Sun ZJ, Shi ZJ, Xu F, Sun RC: Impact of hot compressed water pretreatment on the structural changes of woody biomass for bioethanol production. BioResources 2011, 6:1576-1598.

12. Selig MJ, Viamajala S, Decker SR, Tucker MP, Himmel ME, Vinzant TB: Deposition of lignin droplets produced during dilute acid pretreatment of maize stems retards enzymatic hydrolysis of cellulose. Biotechnol Progr 2007, 23:1333-1339.

13. Hsu W, Schwald W, Schwald MJ, Shields MJ: Chemical and physical changes required for producing dimensionally stable wood-based composites. Wood Sci Technol 1988, 22:281-289.

14. Boonstra MJ, Pizzi A, Ohlmeyer M, Paul W: The effects of a two stage heat treatment process on the properties of particleboard. Holz Roh Werkst 2006, 64:157-164.

15. Okuda N, Hori K, Sato M: Chemical changes of kenaf core binderless boards during hot pressing (I): influence of the pressing temperature condition. J Wood Sci 2006, 52:244-248.

16. Hashim R, Nadhari WNAW, Sulaiman O, Kawamura F, Hiziroglu S, Sato M, Sugimoto T, Seng TG, Tanaka R: Characterization of raw materials and manufactured binderless particleboard from oil palm biomass. Mater Design 2011, 32:246-254

17. Mancera C, Ferrando F, Salvado J: Cynara cardunculus as raw material for the production of binderless fiberboards: optimization of pretreatment and pressing conditions. J Wood Chem Technol 2008, 28:207-226.

18. Okuda N, Hori K, Sato M: Chemical changes of kenaf core binderless boards during hot pressing (II): effects on the binderless board properties. J Wood Sci 2006, 52:249-254.

19. Björkman A: Studies on finely divided wood: part 1: extraction of lignin with neutral solvents. Sven Papperstidn 1956, 59:477-485.

20. Ikeda T, Holtman K, Kadla JF, Chang H-m, Jameel H: Studies on the effect of ball milling on lignin structure using a modified DFRC method. J Agric Food Chem 2001, 50:129-135.

21. Whiting P, Goring D: The morphological origin of milled wood lignin. Sven Papperstidn 1981, 84:120-122.

22. Whiting P, Goring D: Chemical characterization of tissue fractions from the middle lamella and secondary wall of black spruce tracheids. Wood Sci Technol 1982, 16:261-267.

23. Chang $\mathrm{H}$, Cowling EB, Brown W: Comparative studies on cellulolytic enzyme lignin and milled wood lignin of sweetgum and spruce. Holzforschung 1975, 29:153-159.

24. Hu Z, Yeh T-F, Chang H-m, Matsumoto Y, Kadla JF: Elucidation of the structure of cellulolytic enzyme lignin. Holzforschung 2006, 60:389-397.

25. Prinsen P, Gutiérrez A, Rencoret J, Nieto L, Jiménez-Barbero J, Burnet A, Petit-Conil M, Colodette JL, Martínez ÁT, del Río JC: Morphological characteristics and composition of lipophilic extractives and lignin in Brazilian woods from different eucalypt hybrids. Ind Crops Prod 2012, 36:572-583.

26. JIS - A 5908: Particleboards. Japanese Industrial Standard (JIS). Japanese Standards Association, Tokyo, Japan. 2003:1-24

27. GB/T 11718-2009: Medium density fibreboard. China National Standard. Standardization Administration of the People's Republic of China. Beijing, China. 2009:1-32.

28. Nadhari WNAW, Hashim R, Sulaiman O, Sato M, Sugimoto T, Selamat ME: Utilization of oil palm trunk waste for manufacturing of binderless particleboard: optimization study. BioResources 2013, 8:1675-1696.

29. Oh SY, Yoo DI, Shin Y, Seo G: FTIR analysis of cellulose treated with sodium hydroxide and carbon dioxide. Carbohydr Res 2005, 340:417-428. 
30. Poletto M, Pistor V, Santana RMC, Zattera AJ: Materials produced from plant biomass: part II: evaluation of crystallinity and degradation kinetics of cellulose. Mater Res 2012, 15:421-427.

31. Ninomiya K, Kamide K, Takahashi K, Shimizu N: Enhanced enzymatic saccharification of kenaf powder after ultrasonic pretreatment in ionic liquids at room temperature. Bioresour Technol 2012, 103:259-265

32. Cao S, Aita GM: Enzymatic hydrolysis and ethanol yields of combined surfactant and dilute ammonia treated sugarcane bagasse. Bioresour Technol 2013, 131:357-364

33. Silva MR, Machado GO, Brito JO, Calil Junior C: Strength and stiffness of thermally rectified eucalyptus wood under compression. Mat Res 2013, 16:1077-1083.

34. Kumar R, Mago G, Balan V, Wyman CE: Physical and chemical characterizations of corn stover and poplar solids resulting from leading pretreatment technologies. Bioresour Technol 2009, 100:3948-3962.

35. Faix O: Classification of lignins from different botanical origins by FT-IR spectroscopy. Holzforschung 1991, 45:21-28.

36. Ibarra D, Chávez MI, Rencoret J, del Río JC, Gutiérrez A, Romero J, Camarero S, Martínez MJ, Jiménez-Barbero J, Martínez ÁT: Structural modification of eucalypt pulp lignin in a totally chlorine-free bleaching sequence including a laccase-mediator stage. Holzforschung 2007, 61:634-646.

37. Xiao LP Shi ZI, Xu F, Sun RC: Characterization of MWLs from Tamarix ramosissima isolated before and after hydrothermal treatment by spectroscopical and wet chemical methods. Holzforschung 2012, 66:295-302.

38. Villaverde JJ, Li J, Ek M, Ligero P, de Vega A: Native lignin structure of Miscanthus $x$ giganteus and its changes during acetic and formic acid fractionation. J Agric Food Chem 2009, 57:6262-6270.

39. Yelle DJ, Ralph J, Frihart CR: Characterization of nonderivatized plant cell walls using high-resolution solution-state NMR spectroscopy. Magn Reson Chem 2008, 46:508-517.

40. Kim H, Ralph J: Solution-state 2D NMR of ball-milled plant cell wall gels in DMSO- $d_{6}$ /pyridine- $d_{5}$. Org Biomol Chem 2010, 8:576-591.

41. Rencoret J, Gutiérrez A, Nieto L, Jiménez-Barbero J, Faulds CB, Kim H, Ralph J, Martínez ÁT, José C: Lignin composition and structure in young versus adult Eucalyptus globulus plants. Plant Physiol 2011, 155:667-682.

42. Samuel R, Foston M, Jaing N, Cao S, Allison L, Studer M, Wyman C, Ragauskas AJ: HSQC (heteronuclear single quantum coherence) ${ }^{13} \mathrm{C}-{ }^{1} \mathrm{H}$ correlation spectra of whole biomass in perdeuterated pyridinium chloride-DMSO system: an effective tool for evaluating pretreatment Fuel 2011, 90:2836-2842.

43. Li J, Henriksson G, Gellerstedt G: Lignin depolymerization/repolymerization and its critical role for delignification of aspen wood by steam explosion. Bioresour Technol 2007, 98:3061-3068.

44. Xiao LP, Shi ZJ, Xu F, Sun RC: Characterization of lignins isolated with alkaline ethanol from the hydrothermal pretreated Tamarix ramosissima. Bioenerg Res 2013, 6:519-532.

45. Rencoret J, Marques G, Gutiérrez A, Nieto L, Santos Jl, JiménezBarbero J, Martínez ÁT, del Río JC: HSQC-NMR analysis of lignin in woody (Eucalyptus globulus and Picea abies) and non-woody (Agave sisalana) ball-milled plant materials at the gel state. Holzforschung 2009, 63:691-698.

46. Cetinkol ÖP, Smith-Moritz AM, Cheng G, Lao J, George A, Hong K, Henry R, Simmons BA, Heazlewood JL, Holmes BM: Structural and chemical characterization of hardwood from tree species with applications as bioenergy feedstocks. PLoS One 2012, 7:e52820.

47. Kawai $\mathrm{S}$, Nakagawa $\mathrm{M}$, Ohashi $\mathrm{H}$ : Degradation mechanisms of a nonphenolic $\beta$-O-4 lignin model dimer by Trametes versicolor laccase in the presence of 1-hydroxybenzotriazole. Enzyme Microb Technol 2002, 30:482-489.

48. Gutiérrez A, Rencoret J, Cadena EM, Rico A, Barth D, del Río JC, Martínez ÁT: Demonstration of laccase-based removal of lignin from wood and non-wood plant feedstocks. Bioresour Technol 2012, 119:114-122.

49. Muheim A, Fiechter A, Harvey PJ, Schoemaker HE: On the mechanism of oxidation of non-phenolic lignin model compounds by the laccase-ABTS couple. Holzforschung 1992, 46:121-126.

50. Granata A, Argyropoulos DS: 2-Chloro-4,4,5,5-tetramethyl-1,3,2dioxaphospholane, a reagent for the accurate determination of the uncondensed and condensed phenolic moieties in lignins. J Agric Food Chem 1995, 43:1538-1544.
51. Chandra R, Bura R, Mabee W, Berlin A, Pan X, Saddler J: Substrate pretreatment: the key to effective enzymatic hydrolysis of lignocellulosics? Biofuels 2007, 108:67-93.

52. El Hage R, Brosse N, Sannigrahi P, Ragauskas A: Effects of process severity on the chemical structure of Miscanthus ethanol organosolv lignin. Polym Degrad Stab 2010, 95:997-1003.

53. Ramos LP: The chemistry involved in the steam treatment of lignocellulosic materials. Quim Nova 2003, 26:863-871.

54. GB/T 17657-1999: Test methods of evaluating the properties of woodbased panels and surface decorated wood-based panels. China National Standard. Beijing, China: Standardization Administration of the People's Republic of China; 1999:393-451.

55. Sluiter A, Hames B, Ruiz R, Scarlata C, Sluiter J, Templeton D, Crocker D: Determination of structural carbohydrates and lignin in biomass. Golden, CO, USA: National Renewable Energy Laboratory analytical procedure. NREL/ TP-510-42618; 2008.

56. Bai $Y Y$, Xiao LP, Shi ZJ, Sun RC: Structural variation of bamboo lignin before and after ethanol organosolv pretreatment. Int J Mol Sci 2013, 14:21394-21413.

57. Hallac BB, Sannigrahi P, Pu Y, Ray M, Murphy RJ, Ragauskas AJ: Biomass characterization of Buddleja davidii: a potential feedstock for biofuel production. J Agric Food Chem 2009, 57:1275-1281.

58. Cateto CA, Barreiro MF, Rodrigues AE, Brochier-Salon MC, Thielemans W, Belgacem MN: Lignins as macromonomers for polyurethane synthesis: a comparative study on hydroxyl group determination. J Appl Polym SCi 2008, 109:3008-3017.

59. Monteil-Rivera F, Huang GH, Paquet L, Deschamps S, Beaulieu C, Hawari J: Microwave-assisted extraction of lignin from triticale straw: optimization and microwave effects. Bioresour Technol 2012, 104:775-782.

doi:10.1186/2043-7129-2-9

Cite this article as: Xiao et al:: Unraveling the structural characteristics of lignin in hydrothermal pretreated fibers and manufactured binderless boards from Eucalyptus grandis. Sustainable Chemical Processes 2014 2:9.

\section{Publish with ChemistryCentral and every scientist can read your work free of charge \\ "Open access provides opportunities to our colleagues in other parts of the globe, by allowing anyone to view the content free of charge."}

W. Jeffery Hurst, The Hershey Company.

- available free of charge to the entire scientific community

- peer reviewed and published immediately upon acceptance

- cited in PubMed and archived on PubMed Central

- yours - you keep the copyright

Submit your manuscript here:

http://www.chemistrycentral.com/manuscript/<smiles>c1ccccc1</smiles>

Chemistry Central 